\title{
Perceptions Of Reading Assignments: A Comparison Of Business Students And Professors
}

Kay H. Braguglia, (E-mail: kay.braguglia@hamptonu.edu), Hampton University

\begin{abstract}
How do the perceptions of reading assignments of students and professors differ? This study surveyed undergraduate business students and professors to address this question. A review of literature indicated that professors believe that reading assignments are an important part of the learning process while students view reading as less important. Two questionnaires were developed; one for professors and one for students. One hundred four students and twenty-two professors participated in the study. Cluster sampling was used to select student participants and all business school professors were polled. The results will assist with the understanding of college teaching and the development of teaching methods.
\end{abstract}

The findings of this survey are that professors and students have similar perceptions concerning textbook requirements, the percentage of students who buy textbooks, and the number of pages required for weekly readings. The results indicate that $95 \%$ of professors and $93 \%$ of the students say that a textbook is required for business courses. The professors believe that $70 \%$ of the students buy textbooks and $77 \%$ of the students indicated that they actually did buy their books. The perception of professors and students concerning the number of pages assigned were similar with $69.9 \%$ of the students and $73.9 \%$ of the professors indicating that from one to fifty pages was the average weekly assignment.

The findings also suggest that professors and students differ in their perceptions of the importance of reading the textbook to course grades, the percentage of examination questions derived from the textbook, student understanding of reading materials, and whether a student can earn an " $A$ " in a course without reading the textbook. Ninety-five percent of the Professors compared to 52.4\% of the students believe that reading the textbook is important or very important to course grades. When asked where examination questions came from $78.1 \%$ of the professors and only $32.7 \%$ of the students said that $60 \%$ or more of the test questions come from textbooks. A total of $82.6 \%$ of the professors and $48.1 \%$ of the students indicated that students often or always understand textbook readings without explanation. This results in $51.9 \%$ of the students stating that they understand the textbook only sometimes, rarely or never without explanation. Thirty-four percent of the students agreed or strongly agreed that it is easy to make an A or B in a course without reading the textbook and only $4.3 \%$ of the professors believed that a student could make an A or B in the classes they teach without reading the textbook.

\section{STATEMENT OF THE PROBLEM AND RESEARCH QUESTION}

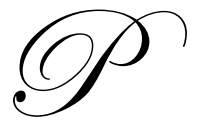

rofessors often emphasize that reading is both beneficial and compulsory indicating that reading assignments are strict requirements for their courses. They believe that reading assignments are an important part of the learning process. However, a review of the literature suggests that students view reading as less important. How do the perceptions of reading assignments of students and professors differ? This study surveyed undergraduate business students and professors to address this question. 
The results of this research will provide a better understanding of the differences and/or similarities in how students and professors view textbook and other assigned readings. If students and professors have differing opinions on the value of textbooks and course reading assignments, the findings could impact on college teaching methods.

\section{PERCEPTIONS OF READING HABITS}

Educators and researchers have not conducted extensive investigations on college students' reading ability and habits. Burchfield and Sappington, (2000) report a review of 19 issues of Teaching of Psychology between 1993 and 1998 that found one article out of 300 with the word reading in the title. While research on reading and college students is limited, reports of inadequate reading and study skills have existed since the $19^{\text {th }}$ century (Bichy, 2003). Jenkins (1928) categorized college students into those who absorb complex material, those who read best selling books, and those who read newspapers and magazines to keep busy. Kingston (1986) found that reading rates among college students had dropped during the 1970's and 1980's. The familiar refrain was that students of this generation do not read and are strangers to points of reference and underlying cadences that govern the development of written English. They cannot write because they do not read (Atlas, 1990). The National Endowment for the Arts (NEA) surveyed 17,000 individuals and discovered that in 198257 percent of adult Americans read literature and in 2004 the figure had fallen to 46.7 percent. The NEA study did not include nonfiction or college student reading. However, the rate of decline for the youngest adults, those aged 18 to 24 , was 55 percent greater than that of the total adult population. Not only are the reading rates of young adults declining but this is true in younger children. In 2005, the National Assessment of Educational Progress (NAEP) reported that reading scores for eighth graders indicate that less than one third are proficient readers. Reading and vocabulary isn't typically taught in the upper grades from which high schools and then colleges receive their students (Tomsho, 2005).

Research on college students' compliance with reading assignments is limited. However, an increasing trend of noncompliance with reading assignments has been reported for the last several years. Burchfield and Sappington (2000) found that in an interval of 16 years students became less and less inclined to even start their assigned readings before class meetings. On a given day less that a third of the students in a population of 910 had completed the assigned readings. Connor-Greene (2000) found that $72 \%$ of the students reported that they rarely or never read their assignments by the due date. Braguglia (2005) found that $42 \%$ of business students read from a textbook daily another $42 \%$ read weekly and $16 \%$ read textbooks monthly or less. In a survey designed to observe the study habits of college students, it was determined that even students who were succeeding at a highly competitive major university benefited from efficient study strategies. When average and advanced students enter college from high school, they encounter learning contexts previously unknown to them, and for which they have no experience or training (Bichy, 2003).

Professors make assumptions about students' reading habits and abilities before coming to decisions about reading assignments for a particular course. These assumptions relate to the speed and efficacy of reading together with the recognition and appreciation of the significance of materials to be read. Professors expect students to be efficient and proficient readers. They do not consider whether students are capable of reading and understanding assignments. Many college professors require students to read 100-150 pages of material per week. When this is multiplied by 4 or 5 courses per semester it equates to 400 or more pages per week (Glencoe, 2004). Although professors are generally enthusiastic about the value of preparatory reading, students are somewhat less so. A common observation among college professors is that their students do not seem particularly motivated to read the assigned readings, especially on a regular basis. Students come to class unprepared and many save the readings until the night before the exam. This problem is universal enough that it tends to be a source of irritation and frustration for many college professors (Instructional Consulting, 2002).

There is some indication that professors and students have different opinions as to the value and necessity of textbooks. In one study, 55 percent of the faculty considered textbooks very important compared to 49 percent of college students (Pringle, 1996). Sappington et al, (2002) found that the vast majority of students believe that reading the textbook is an unimportant activity despite the widespread use of text-based test banks for instructor's examinations. In fact, the National Association of College Stores (2002) reports that 70 percent of college professors base examinations on information found in textbooks. If students see textbooks as less important for success in 
courses than their professors do, this assumption about the value of the textbook can translate into lax reading habits. While the percentage of college courses that require a textbook has dropped in recent years, 86 percent of college courses still require a textbook, 26 percent require some material in electronic format, and 36 percent require a course pack, reader or customized material. However, a required textbook is not a guarantee that a textbook will be purchased. Students purchase 85 percent of their required texts, down from 91 percent in 1999 and 94 percent in 1998. Just over half (55 percent) purchase all of their required course material (National Association of College Stores, 2004).

Many college students today are not strong readers; they regularly report that they don't like to read. If their peers report reading in a given course isn't all that essential, students are only too ready to read half-heartedly or not at all. Connor-Green (2000) reported that $72 \%$ of students rarely or never read their assignments before the due date. Sappington, et al (2002) found that there was a subgroup among non readers who actually preformed well without timely preparation. However, more that half of the non readers earned Ds and Fs on their final exams. Burchfield \& Sappington, (2000) also found that the majority of students cannot pass an easy initial quiz over reading materials and the percentage of students who did pass declined over a 16 year period. Burroughs, Kearney, and Plax (1989) coined the term destructive resistance for failing to do homework, coming to class unprepared, and declining to participate in classroom discussions. Karp \& Yoels, (1976) found that not only do many students fail to study they may not read the assigned material prior to class. This failure to read assignments adversely affects learning and achievement and is a strong predictor of nonparticipation.

The trend in student reading has negative implications for the future of higher education. The National Endowment of the Arts (NEA) indicates that reading is essential to academic success and to intellectual growth. It is believed that decline of reading threatens not only America's arts heritage but its economic position in the world as well. Reading requires sustained focused attention, working with the powers of memory and imagination. Economic success depends on innovation and creativity which comes from reading. Television, video games, and even the internet are more passive than reading. Reading forces the reader to think; watching allows escape. College students nowadays do not have the traditional sense of the role that reading plays in the development of one's life (NEA, 2004).

\section{RESEARCH METHOD}

Undergraduate students and professors in the School of Business were surveyed in the spring semester of 2005. The school has an enrollment of 1,152 full time undergraduate students in eight areas including accounting, business administration, economics, entrepreneurship, management, marketing, and finance. Cluster sampling was used to identify participants. All courses offered during the spring semester 2005 were listed and from this list a random selection of 10 courses was made. Student participants were surveyed in the selected courses. All teaching faculty including professors, associate professors, and assistant professors in the School of Business were surveyed.

Two questionnaires were developed for this study. Completion of the questionnaire required about ten minutes and was in a self-reporting, paper and pencil format. Questionnaires were distributed to selected student participants during a class period. They were briefly informed about the research project and were assured that their responses would remain anonymous and confidential. The surveys were given out and collected back at the beginning or end of the class period. A total of 104 questionnaires were completed by business majors. Twenty-two faculty members in the School of Business completed a questionnaire. After the survey was completed, the responses were tallied and categorized. The data was summarized using descriptive statistics and percentages were calculated.

\section{SURVEY RESULTS}

The findings of this survey are that professors and students have similar perceptions concerning textbook requirements, the percentage of students who purchase textbooks, and the number of pages required for weekly readings. The results indicate that $95 \%$ of professors and $93 \%$ of the students say that a textbook is required for business courses. The professors believe that $70 \%$ of the students buy textbooks and $77 \%$ of the students indicated that they actually did buy their books. The perception of professors and students concerning the number of pages 
assigned were similar with $69.9 \%$ of the students and $73.9 \%$ of the professors indicating that from one to fifty pages was the average weekly assignment made in textbooks. Assignments of reading materials other than textbooks such as journal articles, course packs, and web sites were similar, with $73 \%$ of the students indicating that they were assigned other materials on a weekly basis. Only $60.9 \%$ of the professors indicated that they made such assignments. Both students $(75 \%)$ and professors $(69.6 \%)$ believe that students learn more from lecture/notes than they do from other classroom activities including reading.

Table 1

Which Do Students Learn More From?

\begin{tabular}{|c|c|c|c|}
\hline & Reading Assignments & Lecture/Notes & Other \\
\hline Students & 12.5 & 75.0 & 12.5 \\
\hline Professors & 13.0 & 69.6 & 17.4 \\
\hline
\end{tabular}

Note: Tabled values are percentages and may not equal 100 due to rounding

The findings suggest that professors and students differ in their perceptions of reading assignments in several areas. One difference is their opinions of student noncompliance with reading assignments. Twenty four percent of the students never read assignments before class while professors believe that only $4.3 \%$ of the students read $0 \%$ of the time before class. Over $70 \%$ of the students read assignments $20 \%$ of the time or less before attending class while $52.1 \%$ of the professors believe that students read assignments $20 \%$ of the time or less before class.

Table 2

Percentage of Time Textbook Assignments Are Read by Students Before Class

\begin{tabular}{|c|c|c|c|c|c|c|c|c|c|c|c|}
\hline & $\mathbf{0}$ & $\mathbf{1 0}$ & $\mathbf{2 0}$ & $\mathbf{3 0}$ & $\mathbf{4 0}$ & $\mathbf{5 0}$ & $\mathbf{6 0}$ & $\mathbf{7 0}$ & $\mathbf{8 0}$ & $\mathbf{9 0}$ & $\mathbf{1 0 0}$ \\
\hline Students & 24.0 & 25.0 & 21.2 & 7.7 & 6.7 & 10.6 & 2.9 & 1 & 1 & 0 & 0 \\
\hline Professors & 4.3 & 21.7 & 26.1 & 13.0 & 13.0 & 13.0 & 8.7 & 0 & 0 & 0 & 0 \\
\hline
\end{tabular}

Note: Tabled values are percentages and may not equal 100 due to rounding

A total of $82.6 \%$ of the professors and $48.1 \%$ of the students indicated that students often or always understand textbook readings without explanation. This results in $51.9 \%$ of the students stating that they understand the textbook only sometimes, rarely or never without explanation. Professors indicated that $0 \%$ of the students rarely or never understood text book readings without explanation.

Table 3

Percentage of Students Understanding Readings Without Explanation

\begin{tabular}{|c|c|c|c|c|c|}
\hline & Never & Rarely & Sometimes & Often & Always \\
\hline Students & 1.9 & 12.5 & 37.5 & 46.2 & 1.9 \\
\hline Professors & 0 & 0 & 17.4 & 60.9 & 21.7 \\
\hline
\end{tabular}

Note: Tabled values are percentages and may not equal 100 due to rounding

Professors and students differ in their perceptions of the importance of reading the textbook to course grades. Ninety-five percent of the professors compared to $52.4 \%$ of the students believe that reading the textbook is important or very important to course grades. A total of $47.6 \%$ of the students are neutral or believe that reading assignments are unimportant or very unimportant compared to $4.3 \%$ of the professors.

Table 4

Importance of Textbook Readings to Student Grades

\begin{tabular}{|c|c|c|c|c|c|}
\hline & $\begin{array}{c}\text { Very } \\
\text { Unimportant }\end{array}$ & Unimportant & Neutral & Important & Very Important \\
\hline Students & $6.8 \%$ & 10.7 & 30.1 & 43.7 & 8.7 \\
\hline Professors & 4.3 & 0.0 & 0.0 & 52.3 & 43.5 \\
\hline
\end{tabular}

Note: Tabled values are percentages and may not equal 100 due to rounding 
Professors and students differed in what they believed was the most important to course grades. The students placed more value on lecture notes with $69.2 \%$ believing that they were most important to course grades. Professors on the other hand were almost evenly divided between reading, notes, and other classroom activities.

Table 5

Activities Most Important To Course Grades

\begin{tabular}{|c|c|c|c|}
\hline & Reading Assignments & Lecture/Notes & Other \\
\hline Students & 16.3 & 69.2 & 14.4 \\
\hline Professors & 30.4 & 34.8 & 34.8 \\
\hline
\end{tabular}

Note: Tabled values are percentages and may not equal 100 due to rounding

Students and professors have different perceptions as to whether a student can make an " $\mathrm{A}$ " in a class without reading the text book. Thirty-four percent of the students agreed or strongly agreed that it is easy to make an A or B in a course without reading the textbook and only $4.3 \%$ of the professors believed that a student could make an A or B in their classes without reading the textbook.

Table 6

It Is Easy To Make An "A" Without Reading Textbook

\begin{tabular}{|c|c|c|c|c|c|}
\hline & $\begin{array}{c}\text { Strongly } \\
\text { Disagree }\end{array}$ & Disagree & Neutral & Agree & Strongly Agree \\
\hline Students & 7.7 & 26.9 & 30.8 & 26.9 & 7.7 \\
\hline Professors & 0.0 & 34.8 & 60.9 & 4.3 & 0.0 \\
\hline
\end{tabular}

Note: Tabled values are percentages and may not equal 100 due to rounding

When asked where examination questions came from $78.3 \%$ of the professors compared to $32.7 \%$ of the students said that $60 \%$ or more of the test questions come from textbooks. More than $53 \%$ of the students believe that $50 \%$ or less of the test questions come from the text book compared to $21.6 \%$ of the professors. Over thirteen percent of the students indicated that they do not know where test questions come from.

Table 7

Percentage of Test Questions Are From Textbook

\begin{tabular}{|c|c|c|c|c|c|c|c|c|c|c|c|c|}
\hline & $\mathbf{0}$ & $\mathbf{1 0}$ & $\mathbf{2 0}$ & $\mathbf{3 0}$ & $\mathbf{4 0}$ & $\mathbf{5 0}$ & $\mathbf{6 0}$ & $\mathbf{7 0}$ & $\mathbf{8 0}$ & $\mathbf{9 0}$ & $\mathbf{1 0 0}$ & $\begin{array}{c}\text { Don't } \\
\text { Know }\end{array}$ \\
\hline Students & 1.0 & 5.8 & 5.8 & 17.3 & 7.7 & 16.3 & 4.8 & 8.7 & 4.8 & 13.5 & 1.0 & 13.5 \\
\hline Professors & 0.0 & 0.0 & 4.3 & 4.3 & 0.0 & 13.0 & 13.0 & 17.4 & 21.7 & 13.0 & 13.0 & 0.0 \\
\hline
\end{tabular}

Note: Tabled values are percentages and may not equal 100 due to rounding

The findings suggest that professors and students differ in their perceptions of the percentage of students who read assignments before class, student understanding of reading materials without explanation, the importance of reading the textbook to student grades, the percentage of examination questions derived from the textbook, and whether a student can earn an "A" in a course without reading the textbook.

\section{SUMMARY OF READING COMPLIANCE}

Conventional wisdom says that reading is thought to be important in college courses. However, it seems that the professors are the ones who believe this whereas students do not place as much importance on reading assignments. In a business classroom, 23\% of the students do not purchase the required textbook, $24 \%$ never read assigned materials before class, $14.4 \%$ of the students report that they rarely or never understand the text books without explanation, $47.6 \%$ are neutral or believe that reading assignments are unimportant or very unimportant to 
course grades, $32.7 \%$ think that $60 \%$ or more of test questions come from the textbook, and $34.6 \%$ agree that it is easy to make "A" without reading the textbook. College professors on the other hand, think that $30 \%$ of the students did not purchase the text book, $4.3 \%$ of the students never read assignments before class, $0 \%$ believe that students do not understand the textbook without explanation, $4.3 \%$ are neutral or believe that reading assignments are unimportant or very unimportant to course grades, $78.3 \%$ think that $60 \%$ or more of test questions come from the textbook and $4.3 \%$ agree that it is easy to make an "A" without reading the textbook.

This study shows that college students and professors have different perceptions concerning the importance of reading assignments. The professors place much more emphasis on reading assignments as a source for test questions and course grades than do students. Professors seem to be unaware that $14 \%$ of the students do not understand assigned readings without explanation. Students place a higher emphasis on lecture/notes and do not believe that reading assignments are as important to tests and course grades as their professors do. Professors also do not think students can earn an " $\mathrm{A}$ " or "B" in their classes without reading whereas $34.6 \%$ of the students believe they can.

\section{REFERENCES}

1. Atlas, J. (1990). Battle of the books: The curriculum debate in America. New York: W.W. Norton \& Co.

2. Bichy, C. L. (2003). Reading and study skills, Retrieved on November 7, 2004, from University of Maryland Baltimore Campus Web Site: http://www.umbc.edu/sss/reading skills.html

3. Burroughs, N.F., Kearney. P., \& Plax, T. G. (1989). Compliance resistance in the college classroom. Communication Education, 38 214-229.

4. Braguglia, K. (2005) Reading Habits of Business Students. Journal of College Teaching and Learning, 2 (3) 67-72.

5. Burchfield, C. M. \& Sappington, J. (2000). Compliance with required reading assignments. Teaching of Psychology, 27, 58-60.

6. Connor-Greene, P.A. (2000). Assessing and Promoting student learning: Blurring the line between teaching and testing. Teaching of Psychology, 27, 84-88.

7. Glencoe/McGraw-Hill. (2004). Study tips beyond high school, Teaching tips of the week. Retrieved Oct 21, 2004 from http://www.glencoe.com/sec/teachingtoday/weeklytips.phtml/197.

8. Instructional Consulting. (2002). What to do when Students do not Read? Retrieved November 8, 2004 from http://www.indiana.edu/ icy/noread.html

9. Jenkins, M. (1928). The reading public. In G.C. Clancy (Ed.), Thought and expression: A course in thinking and writing for college students. (20-24), New York: Harcourt, Brace.

10. Karp, D.A. \& Yoels, W. C. (1976). The college classroom: Some observation on the means of student participation. Sociology and Social Research, 60, 421-439.

11. Kingston, P. (1986). Teachers and books in the 1980's. In Baker (ed.) Student reading needs in higher education (107-179). London: Library Association

12. National Association of College Stores. (2004, January 21) Course materials \& purchase factors. Collegiate Market Watch: Research for College Retailers, 131. Retrieved November 17, 2004 from http://www.nacs.org/members/secure/research/marketwatch/131/asp

13. National Association of College Stores. (2002, August 5) Textbooks: perceptions and reality Collegiate Market Watch: Research for College Retailers, 121. Retrieved November 17, 2004 from http://www.nacs.org/members/secure/research/marketwatch/121/asp

14. National Endowment for the Arts. (2004) Reading at Risk. Retrieved November 16, 2004 from http://www.nea.gov/news/news04/ReadingatRisk.html

15. Pringle, T. (1996). And the assigned reading is: students, faculty rate texts. The Daily Cougar. Retrieved November 17, 2004 from http://www.stp.uh.edu/vol62/66/Campus/camp2/camp2.html.

16. Rosenberg, P. (2004, Monday October 11) Books cost big bucks. Daily Press, Newport News, VA

17. Sapperington, J., Kinsey, K., \& Munsayac, K. (2002). Two studies of reading compliance among college students. Teaching of Psychology, 294272274.

18. Tomsho, R. (2005, Thursday October 20). Reading scores advance little in national test. The Wall Street Journal. B1-2. Dow Jones: New York. 